\title{
OPEM
}

www.opem.org

Oriental Pharmacy and Experimental Medicine 2009 9(2), 192-199

DOI 10.3742/OPEM.2009.9.2.192

\section{In vitro Biological Activity of Germacranolide sesquiterpene lactones}

\author{
Myung-Ju Kim ${ }^{1}$ Jae-Sug Lee ${ }^{2}$ and Seung-Hwa Baek ${ }^{3, *}$ \\ ${ }^{1}$ Department of Skin \& Beauty, Kwangju Health Science College, Kwangju 506-701, Republic of Korea; \\ ${ }^{2}$ Department of Beauty Science, Kwangju Women's University, Kwangju 506-713, Republic of Korea; \\ ${ }^{3}$ Department of Herbal Resources, Professional Graduate School of Oriental Medicine, Wonkwang University, \\ Iksan 570-749, Republic of Korea
}

Received for publication May 08, 2009; accepted June 05, 2009

\begin{abstract}
SUMMARY
Bioactivity-directed isolation has led to the isolation of (-)-ent-costunolide (1) as the major active compound from Hepatostolonophora paucistipula. This compound (1) was determined by spectroscopic data interpretation. This sesquiterpene lactone (1) inhibited the growth of the dermatophytic fungus Trichophyton mentagrophytes ATCC 28185, (4 mm inhibition zone at $15 \mu \mathrm{g} /$ disc), cytotoxic activity to murine leukaemia cell lines ATCC CCL 46 P 388D1 (IC $5067 \mathrm{ng} / \mathrm{ml}$, at $0.075 \mu \mathrm{g} /$ disk), BSC monkey kidney cell lines (100\% of well at $15 \mu \mathrm{g} /$ disk) and antiviral activity to Herpes simplex virus $(0.25 \mathrm{mg} / \mathrm{ml}, 100 \%$ of well at $7.5 \mu \mathrm{g} /$ disk $)$ and Polio virus $(0.125 \mathrm{mg} / \mathrm{ml}, 100 \%$ of well at $3.75 \mu \mathrm{g} /$ disk). These results suggest that (-)-ent-costunolide (1) has potential antimicrobial and cytotoxic agents.
\end{abstract}

Key words: (-)-ent-Costunolide (1); Hepatostolonophora paucistipula; Trichophyton mentagrophytes; Antifungal activity; Cytotoxic activity; Antiviral activity

\section{INTRODUCTION}

Hepatostolonophora paucistipula (Rodw.) J.J. Engel (family Geocalycaceae) is a rich source of sesquiterpenes in the New Zealand liverworts (Asakawa, 1995). There are no literature reports on the biological chemistry of this genus. (-)-ent-arbusculin B has isolated from the whole plant of H. paucistipula, and its structure has been determined by spectroscopic analysis. Sesquiterpene lactone inhibited the growth of the dermatophytic fungus Trichophyton

*Correspondence: Seung Hwa Baek, Department of Herbal Resources, Professional Graduate School of Oriental Medicine, Wonkwang University, Iksan 570-749, Republic of Korea; Tel: +82638506225; Fax: +82638414893; E-mail: shbaek@ wonkwang.ac.kr mentagrophytes ATCC 28185, (2 $\mathrm{mm}$ inhibition zone at $15 \mu \mathrm{g} /$ disc) (Kim et al, 2005). Increasing attention has been paid to primitive medicinal plants to find new substances with potentially useful biological activities.

Sesquiterpene lactones are natural products isolated from many plant families and most widely distributed within the Compositae. These compounds are known for their various biological activities, including cytotoxicity to tumor cells (Beekman et al., 1997). Covalent binding of sesquiterpene lactones to free sulfhydryl groups in proteins and interference with the functions of these macromolecules have been described (Lee et al., 1997; Schmidt, 1997). These compounds react with nucleophiles, especially cysteine sulphydryl groups, by a Michael-type addition (Lyss et al., 1998). Thus, compounds with 
two $\alpha, \beta$-unsaturated carbonyl groups may show considerable cytotoxic properties.

Recently, compounds containinig the R-methylene$\gamma$-lactone functional group, such as sesquiterpene lactones, have attracted much attention during the last 50 years because they display a wide range of biological activities, including antitumor properties (Zhang et al, 2005). The isolation of a formal DielsAlder adduct between an unreactive diene such as myrcene and an acid and thermally unstable poor dienophile such as (-)-ent-costunolide (1) suggests that genepolide is not an isolation artifact but a genuine natural product and that the biogenetic machinery of A. umbelliformis contains DielsAlderase enzymatic activity (Appendino et al, 2009). This observation is important for the hot debate on the existence of enzymes promoting cycloaddition reactions, since all previously reported DielsAlder adducts involving exomethylene sesquiterpene- $\gamma$ lactones involve reactive dienophiles and not a poor partner such as myrcene (Stocking et al, 2003). In addition, remarkable differences were observed in the thermal and acid-catalyzed reactivity of the cyclodecadiene moiety of costunolide and genepolide, suggesting that quaternarization at C-11 has a dramatic effect on the reactivity of the mediumsized diene system of these compounds.

In this study, the antiviral, cytotoxic, and antimicrobial activities of (-)-ent-costunolide (1) from $H$. paucistipula have investigated, and we determined its structure by spectroscopic analysis.

\section{MATERIALS AND METHODS}

\section{General experimental procedures}

All solvents were distilled before use. Solvents from chromatography fractions were removed by rotary evaporation at temperature up to $40^{\circ} \mathrm{C}$. Initial fractionation of crude plant extract using reverse phase column chromatography was performed with octadecyl-functionalized silica gel (C-18 Aldrich) as the adsorbent. Further column fractionation was performed using Davisil silica $60 \AA$ (35-70 $\mu \mathrm{m}$ silica gel, Allth) as adsorbent. TLC was carried out using Merck DC-plastikfolien Kieselgel $60 \mathrm{~F}_{254}$ and visualized first with a UV lamp, then dipped in a vanillin solution (1\% vanillin, $1 \% \mathrm{H}_{2} \mathrm{SO}_{4}$ in $\mathrm{EtOH}$ ) followed by heating. Microanalyses were performed by Marianne Dick and Bob McAllister (Campbel Microanalytical Laboratory, Chemistry Department, University of Otago). MS, UV, and IR spetra were recorded on Krato MS-80, Shimadzu UV 240, and Perkin-Elmer 1600 FT-IR instruments respectively. NMR spectra, of $\mathrm{CDCl}_{3}$ solutions at $25^{\circ} \mathrm{C}$, were recorded at $300 \mathrm{MHz}$ for ${ }^{1} \mathrm{H}-\mathrm{NMR}$ and $75 \mathrm{MHz}$ for ${ }^{13} \mathrm{C}-\mathrm{NM}$ R on a Varian VXR-300 spectrometer. Chemical shifts are given in parts per million on the $\delta$ scale referenced to the solvent peak $\mathrm{CHCl}_{3}$ at $7.25 \mathrm{ppm}$ and $\mathrm{CDCl}_{3}$ at $77.08 \mathrm{ppm}$ and are referenced to TMS at $0.00 \mathrm{ppm}$.

\section{Plant material}

H. paucistipula was collected from Port Adventure, Stewart Island, in January 1994. This was identified by D. Glenny, Landcare Research, and a voucher specimen, OTA 046764, has been kept in the Otago University herbarium.

\section{Isolation of (-)-ent-costunolide (1)}

Air-dried H. paucistipula $(76.3 \mathrm{~g}$ ) was grounded and macrated in redistilled ethanol $(1,000 \mathrm{ml})$ in a Waring Blender, then filtered. The residual marc was re-extracted in the same way with more ethanol $(3 \times 300 \mathrm{ml})$. The combined filtrates were evaporated under reduced pressure to give a crude extract $(1.585 \mathrm{~g})$. A sub-sample $(0.836 \mathrm{~g})$ was fractionated over a $\mathrm{C}_{18}$-bonded silica column $(10 \mathrm{~g})$, developed with $\mathrm{H}_{2} \mathrm{O}, 3: 1,1: 1$, and $1: 3$ mixtures of $\mathrm{H}_{2} \mathrm{O}: \mathrm{CH}_{3} \mathrm{CN}$, then $1: 1-\mathrm{CH}_{3} \mathrm{CN}: \mathrm{CHCl}_{3}$ then $\mathrm{CHCl}_{3}$, then Hexane, followed by extra $\mathrm{CHCl}_{3}$ and $\mathrm{CH}_{3} \mathrm{CN}(2 \times 17 \mathrm{ml}$ fractions for each solvent mixture). Most of the antimicrobial activity was found in fractions eluted with $1: 3-\mathrm{H}_{2} \mathrm{O}: \mathrm{CH}_{3} \mathrm{CN}(34 \mathrm{ml})$. This material $(96 \mathrm{mg})$ was fractionated on a silica gel column (1.0 g), developed with $100 \%$ hexane (4 $\mathrm{ml}), 2 \%(3 \times 4 \mathrm{ml}), 5 \%(6 \times 4 \mathrm{ml}), 10 \%(5 \times 4 \mathrm{ml})$, 
$15 \%(4 \times 4 \mathrm{ml}), 20 \%(10 \times 4 \mathrm{ml}), 30 \%(3 \times 4 \mathrm{ml}), 40 \%$ $(6 \times 4 \mathrm{ml}), 50 \%(5 \times 4 \mathrm{ml}), 75 \%(4 \times 4 \mathrm{ml})$ mixture of ethyl acetate : hexane, then $100 \%$ ethyl actate, then $100 \% \mathrm{EtOH}(5 \times 4 \mathrm{ml})$. Fractions eluted with $5 \%$ ethyl acetate : hexane $(2 \times 4 \mathrm{ml})$ and $10 \%$ ethyl acetate : hexane $(5 \times 4 \mathrm{ml})$ were combined and yielded white crystals $\left(44.0 \mathrm{mg}\right.$, P $388 \mathrm{IC}_{50} 302 \mathrm{ng} / \mathrm{ml}$ ). This material $(44.0 \mathrm{mg})$ was fractionated on a silica gel column (500.0 mg), developed with $100 \%$ hexane $(4 \times 2 \mathrm{ml}), 5 \%(4 \times 2 \mathrm{ml}), 10 \%(5 \times 2 \mathrm{ml}), 15 \%(5 \times 2$ $\mathrm{ml}), 20 \%(5 \times 2 \mathrm{ml}), 25 \%(6 \times 2 \mathrm{ml}), 30 \%(6 \times 2 \mathrm{ml})$, mixture of ethyl acetate : hexane. Fractions eluted with $5 \%$ ethyl acetate : hexane $(4 \times 2 \mathrm{ml})$ and $10 \%$ ethyl acetate : hexane $(2 \times 2 \mathrm{ml})$ were combined and yielded white crystals $\left(37.1 \mathrm{mg}\right.$, P 388 IC $_{50} 945$ $\mathrm{ng} / \mathrm{ml}$ ). The third $\mathrm{P} 388$-active fraction from this column was subjected to preparative Si gel TLC (1: 9 ethyl acetate : hexane) to give (-)-ent-costunolide (1, $14.4 \mathrm{mg}$, P $\left.388 \mathrm{IC}_{50} 687 \mathrm{ng} / \mathrm{ml}\right)$ : courless gum; $[\alpha]^{22}-127^{0},[\alpha]_{577 \mathrm{~nm}}^{25}-175^{0},[\alpha]_{546 \mathrm{~nm}}^{25}-233^{0},[\alpha]_{435}^{25} \mathrm{~nm}^{-}$ $621^{0},[\alpha]^{25}{ }_{405} \mathrm{~nm}^{-}-748^{0},\left(\mathrm{c}, 0.075, \mathrm{CHCl}_{3}\right)$; lit. $[\alpha]_{\mathrm{D}}-35^{0}$, $\left(\mathrm{CHCl}_{3}\right)$; silica TLC $\mathrm{R}_{\mathrm{F}} 0.20$ (1: 9 - ethyl acetate : hexane); $\mathrm{UV}_{\lambda \max }(\mathrm{MeOH}) \mathrm{nm}(\log \varepsilon) 224$ (4.00); $\mathbb{R}_{v \max }$ (film), 2921, 2856, 1763, 1665, 1442, 1382, 1289, 1246, $1137,968,755 \mathrm{~cm}^{-1} ;{ }^{1} \mathrm{H}-\mathrm{NMR}\left(\mathrm{CDCl}_{3}\right): \delta 6.27(1 \mathrm{H}, \mathrm{d}$, $\mathrm{J}=3.6 \mathrm{~Hz}, 13 \mathrm{\prime}-\mathrm{H}), 5.53(1 \mathrm{H}, \mathrm{d}=3.3 \mathrm{~Hz}, 13-\mathrm{H}), 4.86$ $(1 \mathrm{H}$, brdd, J=6.6, $10.8 \mathrm{~Hz}, 1-\mathrm{H}), 4.75(1 \mathrm{H}, \mathrm{brd}, \mathrm{J}=10.2$ $\mathrm{Hz}, 5-\mathrm{H}), 4.58(1 \mathrm{H}, \mathrm{dd}, \mathrm{J}=8.7,9.6 \mathrm{~Hz}, 6-\mathrm{H}), 2.58(1 \mathrm{H}$, m, 7-H), 2.46 (1H, brdd, J=3.9, $\left.13.5 \mathrm{~Hz}, 3^{\prime}-\mathrm{H}\right), 2.0$ $2.4\left(6 \mathrm{H}, \mathrm{m}, 2^{\prime}-\mathrm{H}, 3-\mathrm{H}, 8-\mathrm{H}, 8^{\prime}-\mathrm{H}, 9-\mathrm{H}, 9^{\prime}-\mathrm{H}\right), 1.71$ $\left(3 \mathrm{H}, \mathrm{s}, \mathrm{CH}_{3}\right), 1.67(1 \mathrm{H}, \mathrm{dd}, \mathrm{J}=2.7,5.1 \mathrm{~Hz}, 2-\mathrm{H}), 1.43$ $\left(3 \mathrm{H}, \mathrm{s}, \mathrm{CH}_{3}\right) ;{ }^{13} \mathrm{C}-\mathrm{NMR}\left(\mathrm{CDCl}_{3}\right): \delta 170.52(\mathrm{C}-12)$, 141.52 (C-11), 140.15 (C-4), 137.00 (C-10), 127.33 (C5), 127.12 (C-1), 119.70 (C-13), 81.97 (C-6), 50.49 (C7), 41.07 (C-3), 39.54 (C-9), 28.13 (C-2), 26.27(C-8), 17.42 (C-15), 16.19 (C-14); EI-MS (70 eV): 232.1464 $\left(26 \%, \mathrm{M}^{+}, \mathrm{C}_{15} \mathrm{H}_{22} \mathrm{O}_{2}\right.$ requires 232.1463), 217 (25\%, $\left.\mathrm{M}^{+}-\mathrm{CH}_{5}\right), 149$ (36\%), 136 (15\%), 121 (100\%); A dose of $15 \mu \mathrm{g} /$ disk and $7.5 \mu \mathrm{g} /$ disk showed $100 \%$ inhibition of Herpes simplex and Polio. A dose of $3.75 \mu \mathrm{g} /$ disk showed $75 \%$ inhibition of Herpes simplex and Polio. $15 \mu \mathrm{g} /$ disk gave a $4 \mathrm{~mm}$ zone of inhibition of Bacillus subtilis.

\section{Antiviral activity}

The compound was applied $(30 \mu \mathrm{L}$ of a $0.5 \mathrm{mg} / \mathrm{ml}$ solution) to a small filter-paper disc, dried, and assayed for antiviral activity using Schroeder et al. methods (Asakawa et al., 1987). The results were observed as either cell death (cytotoxicity), inhibition of virus replication, no effect (i.e., all of the cells show viral infection), or a combination of all three. The results were noted as the approximate size of the circular zone, radiating from the extract sample, from $1+$ to $4+$ representing $25 \%$ through to whole well sized zones. The notation used is inhibition/

Table 1. ${ }^{1} \mathrm{H}-\mathrm{NMR}$ spectral data of compounds 1, 2, and 3 (300 MHz, $\left.\mathrm{CDCl}_{3}\right)(\mathrm{Chen}$, et al., 1989)

\begin{tabular}{cccccccccc}
\hline $\mathrm{H}$ & \multicolumn{3}{c}{$\mathbf{1}$} & \multicolumn{3}{c}{$\mathbf{2}$} & \multicolumn{3}{c}{$\mathbf{3}$} \\
\hline 1 & 4.86 & $\mathrm{br} \mathrm{dd}$ & $1 \mathrm{H}$ & 4.84 & $\mathrm{br} \mathrm{dd}$ & $1 \mathrm{H}$ & 5.16 & $\mathrm{t}$, & $1 \mathrm{H}$ \\
2 & 1.67 & $\mathrm{dd}$ & $1 \mathrm{H}$ & 1.67 & $\mathrm{qd}$ & $1 \mathrm{H}$ & $1.76-21$ & $\mathrm{~m}$ & $5 \mathrm{H}$ \\
2 & $2.0-2.4$ & $\mathrm{~m}$ & $6 \mathrm{H}$ & $2.0-2.4$ & $\mathrm{~m}$ & $6 \mathrm{H}$ & - & - & - \\
3 & $2.0-2.4$ & $\mathrm{~m}$ & $6 \mathrm{H}$ & $2.0-2.4$ & $\mathrm{~m}$ & $6 \mathrm{H}$ & $1.76-21$ & $\mathrm{~m}$ & $5 \mathrm{H}$ \\
3 & 2.46 & $\mathrm{br} \mathrm{dd}$ & $1 \mathrm{H}$ & 2.44 & $\mathrm{dd}$ & $1 \mathrm{H}$ & 2.14 & $\mathrm{~m}$ & $1 \mathrm{H}$ \\
5 & 4.75 & $\mathrm{br} \mathrm{d}$ & $1 \mathrm{H}$ & 4.73 & $\mathrm{br} \mathrm{d}$ & $1 \mathrm{H}$ & 5.05 & $\mathrm{dd}$ & $1 \mathrm{H}$ \\
6 & 4.58 & $\mathrm{dd}$ & $1 \mathrm{H}$ & 4.57 & $\mathrm{t}$ & $1 \mathrm{H}$ & 4.57 & $\mathrm{dd}$ & $1 \mathrm{H}$ \\
7 & 2.58 & $\mathrm{~m}$ & $1 \mathrm{H}$ & 2.56 & $\mathrm{t}$ & $1 \mathrm{H}$ & 2.48 & $\mathrm{ddq}$ & $1 \mathrm{H}$ \\
8 & $2.0-2.4$ & $\mathrm{~m}$ & $1 \mathrm{H}$ & $2.0-2.4$ & $\mathrm{~m}$ & $6 \mathrm{H}$ & 1.50 & $\mathrm{dddd}$ & $1 \mathrm{H}$ \\
8 & $2.0-2.4$ & $\mathrm{~m}$ & $6 \mathrm{H}$ & - & - & $6 \mathrm{H}$ & 2.27 & $\mathrm{dddd}$ & - \\
$9 / 9$ & $2.0-2.4$ & $\mathrm{~m}$ & $6 \mathrm{H}$ & $2.0-2.4$ & $\mathrm{~m}$ & $1 \mathrm{H}$ & $1.76-21$ & $\mathrm{~m}$ & $5 \mathrm{H}$ \\
13 & 5.53 & $\mathrm{~d}$ & $1 \mathrm{H}$ & 5.51 & $\mathrm{~d}$ & $1 \mathrm{H}$ & 5.41 & $\mathrm{~d}$ & $1 \mathrm{H}$ \\
13 & 6.27 & $\mathrm{~d}$ & $1 \mathrm{H}$ & 6.26 & $\mathrm{~d}$ & $1 \mathrm{H}$ & 6.14 & $\mathrm{~d}$ & $1 \mathrm{H}$ \\
14 & 1.43 & $\mathrm{~s}$ & $3 \mathrm{H}$ & 1.40 & $\mathrm{~s}$ & $3 \mathrm{H}$ & 1.68 & $\mathrm{~d}$ & $3 \mathrm{H}$ \\
15 & 1.71 & $\mathrm{~d}$ & $3 \mathrm{H}$ & 1.70 & $\mathrm{~s}$ & $3 \mathrm{H}$ & 1.81 & $\mathrm{~d}$ & $3 \mathrm{H}$ \\
\hline
\end{tabular}


Table 2. ${ }^{13} \mathrm{C}-\mathrm{NMR}$ spectral data of compounds $\mathbf{1}, \mathbf{2}$, and $3\left(\mathrm{CDCl}_{3}\right)(\mathrm{Chen}$, et al., 1989)

\begin{tabular}{cccc}
\hline $\mathrm{C}$ & 1 & 2 & 3 \\
\hline 1 & 127.13 & 127.01 & 124,87 \\
2 & 28.13 & 28.18 & 26,71 \\
3 & 41.07 & 41.01 & 38.87 \\
4 & 140.15 & 140.04 & 138.13 \\
5 & 127.33 & 127.23 & 124.45 \\
6 & 81.97 & 81.95 & 80.66 \\
7 & 50.49 & 50.50 & 44.98 \\
8 & 26.27 & 26.33 & 25.41 \\
9 & 39.54 & 39.56 & 25.08 \\
10 & 137.00 & 136.93 & 136.73 \\
11 & 141.52 & 141.11 & 140.1 \\
12 & 170.52 & 170.37 & 170.31 \\
13 & 119.70 & 119.65 & 118.39 \\
14 & 16.19 & 16.28 & 21.91 \\
15 & 17.42 & 17.51 & 17.23 \\
\hline
\end{tabular}

As indicated in Table III, (-)-ent-costunolide (1) inhibited the growth of the dermatophytic fungus Trichophyton mentagrophytes ATCC 28185, (4 mm inhibition zone at $15 \mu \mathrm{g} /$ disc). The activities are expressed by the diameter of the developed inhibition zones and compared with those of the widely antibious chloramphenicol, gentamycin and nystatin (Table III) (Baek et al., 2003). This compound (1) shows the strong antiviral activity against Herpes simplex Type I virus ATCC VR 733 (0.25 $\mathrm{mg} / \mathrm{ml}, 100 \%$ of well at $7.5 \mu \mathrm{g} /$ disk) and Polio Type I virus (Pfizer vaccine strain, $0.125 \mathrm{mg} / \mathrm{ml}, 100 \%$ of well at $3.75 \mu \mathrm{g} /$ disk). This compound was more antimicrobial than (-)-ent-arbusculin B (4) (Kim et al., 2005).

antiviral activity. The type of antiviral effect, indicated by a number after the size of the zone, was also considered important and may give some indication as to the mode of cytotoxic action.

\section{Antibacterial and antiyeast activities}

Activity against the following bacterial strains and yeast was tested: multiresistant Bacillus subtilis (ATCC 19659) Escherichia coli (ATCC 25922), Pseudomonas aeruginosa (ATCC 27853), Cladosporium resinae (ATCC 52833) and Candida albicans (ATCC 14053). The compound was dissolved and diluted in an appropriate solvent (usually ethanol : water) to a concentration of $0.5 \mathrm{mg} / \mathrm{ml}$. Test plates are prepared from Mueller Hinton agar containing extract to give a final concentration of $100 \mu \mathrm{g}$ extract $/ \mathrm{ml}$ agar.
Activity of the growing cultures of the test strains were diluted in saline to deliver $10^{4}$ colony forming units onto the test, control (solvent), and blank (agar only) plates with a multipoint inoculator. Inoculated plates were incubated overnight at $37^{\circ} \mathrm{C}$. Growth on the blank and control plates were checked and, if satisfactory, growth on the test plates were was scored for each test strain. Solutions of compound for assay were dried onto $6 \mathrm{~mm}$ filter paper disks, placed onto seeded agar Petri dishes and then incubated. Activity was observed as a zone of inhibition around the disk, with its width recorded from the edge of the disk in $\mathrm{mm}$. HM and $\mathrm{SM}$ refer to the observed margin surrounding the zone of inhibition. $(\mathrm{H}=$ hazy, $\mathrm{S}=$ sharp$)$.

\section{Antifungal activity}

Fungal spore suspensions of Trichophyton mentagraphytes (ATCC 28185) were applied to dextrose agar plates. Aliquots of the extract solutions were applied to filter paper discs, at $30 \mu \mathrm{g}$ sample/disc, and dried at $37^{\circ} \mathrm{C}$ for two hours. These discs were applied to the agar plates, two per plate, and incubated at $28^{\circ} \mathrm{C}$.

\section{Cytotoxic activity}

This is a measure of the ability of a sample to inhibit the multiplication of murine leukaemia cells. The sample was dissolved in a suitable solvent, usually ethanol, at $0.5 \mathrm{mg} / \mathrm{ml}$, and $30 \mu \mathrm{L}$ of this solution was placed in the first well of a multi-well plate. Seven two-fold dilutions were made across the plate. After the addition of the cell solution, the concentration range in the test wells were between 25,000 to $195 \mathrm{ng} / \mathrm{ml}$. After three day incubation, the plates were read using an ELISA palte reader at $540 \mathrm{~nm}$ wavelength. Automated reading of the plates was possible with the addition of a MTT tetrazolium salt (yellow color). Healthy cells reduce this salt to MTT formazan (purple color). The concentration of the sample required to inhibit cell growth to $50 \%$ of a solvent control was determined using the absorbance obtained upon staining with MTT tetrazolium. Mytomycin C (concentration 0.075 
Table 3. Biological activities of (-)-ent-costunolide (1) from H. paucistipula

\begin{tabular}{|c|c|c|c|c|c|}
\hline \multirow[b]{2}{*}{ Assay } & \multicolumn{5}{|c|}{ Tested material } \\
\hline & $\begin{array}{c}11 \\
\mathbf{1 1 1 1 1} \\
1\end{array}$ & Chloramphenicol & Nystatin & Gentamycin & Mitomycin C \\
\hline Cytotoxicity & & & & & \\
\hline BSC-1 cells ${ }^{\mathrm{a}}$ & ++++ & & & & \\
\hline $\mathrm{P} 388, \mathrm{IC}_{50}$ & $687^{\mathrm{b}}$ & & & & $34.6^{\mathrm{c}}$ \\
\hline Antiviral activity $^{\mathrm{d} d ')}$ & & & & & \\
\hline Herpes simplex virus & $++++(+++)$ & & & & \\
\hline Polio virus & $++++(+++)$ & & & & \\
\hline Antimicrobial activity $^{\mathrm{e}}$ & & & & 0 & \\
\hline B. subtilis & - & SM 13 & & 0 & 0 \\
\hline E. coli & - & 0 & & 0 & SM 9 \\
\hline P. aeruginosa & - & 0 & & HM 10 & SM 11 \\
\hline C. albicans & - & 0 & & HM 10 & 0 \\
\hline C. resinae & - & 0 & & SM 6 & 0 \\
\hline T. mentagrophytes & HM4 & 0 & & & 0 \\
\hline
\end{tabular}

a $\%$ of well showing cytotoxic effects. @ $0.5 \mathrm{mg} / \mathrm{ml}, 15 \mu \mathrm{g} /$ disk; ++++: 100\% activity. Hazy margin, SM; Sharp margin, numbers refer to zone of inhibition $(\mathrm{mm}){ }^{\mathrm{b}}{ }^{\mathrm{T}}$ Toxicity of sample to murine leukaemia cell lines (ATCC CCL 46 P388D1) in $\mathrm{ng} / \mathrm{ml}$ at $0.075 \mu \mathrm{g} /$ disk. P388; Concentration of the sample required to inhibit cell growth to $50 \%$ of a solvent control. ${ }^{\mathrm{C}}$ Toxicity of sample to murine leukaemia cells (ATCC CCL 46 P388D1) in ng/ml at $7.5 \mu \mathrm{g} / \mathrm{disk}$. ${ }^{\mathrm{d} C}$ Cytotoxicity in antiviral assays. @ $0.25 \mathrm{mg} / \mathrm{ml}, 7.5 \mu \mathrm{g} /$ disk; Zone of cytotoxic activity: ++++: $100 \%$ activity. ${ }^{d}$ Cytotoxicity in antiviral assays. @ $0.125 \mathrm{mg} / \mathrm{ml}, 3.75 \mu \mathrm{g} /$ disk; Zone of cytotoxic activity: +++: $75 \%$ activity and +++: $75 \%$ activity. ${ }^{\mathrm{e}}$ Width of zone of inhibition in $\mathrm{mm} ; 15 \mu \mathrm{g} / \mathrm{disk}$; -: not detected, 0 : not determined. Chloramphenicol; 30 mcg/disk, Gentamycin; 30 mcg/disk, Nystatin; 100 unit/disk. HM; Hazy margin, SM; Sharp margin, numbers refer to zone of inhibition ( $\mathrm{mm}$ )

Cytotoxic activity of (-)-ent-costunolide (1)

Normal-phase flash column chromatography concentrated the cytotoxic activity in fraction 3 then eluted with $5 \%$ and $10 \%$ ethyl acetate - hexane. Chromatography on silica gel $(0.5 \mathrm{~g})$ with an ethyl acetate - cyclohexane gradient gave four fractions. The second silica gel column chromatography of subfraction 2 gave most of the mass in the less polar fraction, eluted with 5\% and 10\% ethyl acetate - hexane. Among them, subfraction 2, that eluted with 5\% and $10 \%$ ethyl acetate - hexane, is the most cytotoxic activity to murine leukaemia cells ATCC CCL 46 P388D1 (37.1 mg, P388 IC $50945 \mathrm{ng} / \mathrm{ml}$ at $7.5 \mu \mathrm{g} /$ disc). A comparison of $\mathrm{IC}_{50}(\mathrm{ng} / \mathrm{ml})$ values of these subfractions in cancer cells showed susceptibility to these subfractions decreased in the following order; subfraction $2>4>1=.3$ (Baek et al., 2003; Kim et al., 2009).

The result shows the potent cytotoxic activity of (-)-ent-costunolide (1) from H. paucistipula against P388 murine leukaemia cell lines (P 388 IC $_{50} 687 \mathrm{ng} / \mathrm{ml}$ ) and BSC monkey kidney cell lines (100\% of well at $15 \mu \mathrm{g} /$ disk). The cytotoxic activity of this sesquiterpene lactone was in a dose-dependent inhibition of cell proliferation. This compound showed a dose-dependent increase of cell antiproliferation after treatment with of (-)-ent-costunolide (1) (Baek et al., 2000; Shin et al., 2001). This compound was more cytotoxic than (-)-ent-arbusculin B (4) (Kim et al., 2005). This compound- mediated cytotoxicity was rapidly increased in the MTT method when its concentrations or absorbances were raised from 2.591 to 3.494. However, the other absorbances were most strong cytotoxic. An $\mathrm{IC}_{50}$ of $0.57 \mu \mathrm{g} / \mathrm{ml}$ against KB carcinoma cells has been reported for (+)-costunolide (2) (Fig. 2) (Kupchan et al., 1971).

$\mu \mathrm{g} / \mathrm{ml}$ ) was used as a positive control and inhibited the growth of P388 cells by $43-75 \%$.

\section{RESULTS AND DISCUSSION}

Isolation and identification of (-)-ent-costunolide (1)
We have surveyed the New Zealand liverwort for plant products with potential medicinal and agricultural applications. One of the plant extracts that showed activity in antiviral (Herpes simplex) and antimicrobial (Trichophyton mentagrophyte and Bacillus subtilis) screens came from the liverwort of 
Jungermannia species. This liverwort is a rich source of diterpenoids belonging to the pimarane, clerodane and kaurane classess (Asakawa, 1995). A sub-sample of the extract was subjected to reverse-phase (C-18) silica gel column chromatography. The column fractions were combined based on visually similar TLC results. These combined fractions were assayed against P388 murine leukaemia cell lines (ATCC CCL 46 P388D1) and the activity was found to be spread over six fractions that were eluted with $1: 1$ $\mathrm{H}_{2} \mathrm{O} / \mathrm{MeCN}, 1: 3 \mathrm{H}_{2} \mathrm{O} / \mathrm{MeCN}, \mathrm{MeCN}, 1: 1 \mathrm{MeCN} /$ $\mathrm{CHCl}_{3}, \mathrm{Hex} / \mathrm{CHCl}_{3}$ and $\mathrm{MeCN}$ (Baek et al., 1998). Because of this, the fraction 4 was chromatographed on a silica gel column using a ethyl acetate - hexane gradient. The fraction 4-3 with high activity was shown by TLC and ${ }^{1} \mathrm{H}-\mathrm{NMR}$ spectrum to consist of one main UV-active compound. The subfraction was chromatographed on a silica gel column using a ethyl acetate - hexane gradient. The column subfractions were combined based on visually similar TLC results. These combined subfractions were assayed against $P 388$ murine leukaemia cell lines (ATCC CCL 46 P388D1) and the activity was found to be spread over four subfractions that were eluted with $100 \%$ hexane, $5-10 \%$ ethyl acetate /hexane, $10-15 \%$ ethyl acetate / hexane, and 20$30 \%$ ethyl acetate / hexane. High cytotoxic activity from one main UV-active compound was shown by TLC and ${ }^{1} \mathrm{H}-\mathrm{NMR}$ spectrum from the fraction 4 3-2. Cytotoxic activity was spread across ethyl acetate - hexane 10 : $90\left(R_{f} 0.20\right)$ band containing (-)ent-costunolide (1) in thin-layer chromatography. The MS supported a molecular of $\mathrm{C}_{15} \mathrm{H}_{22} \mathrm{O}_{2}$. The ${ }^{1} \mathrm{H}-\mathrm{NMR}$ spectrum of $\mathbf{1}$ showed the presence of olefinic group with signals at $\delta 5.53(1 \mathrm{H}, \mathrm{d}, \mathrm{J}=3.3$ $\mathrm{Hz})$ and $86.27(1 \mathrm{H}, \mathrm{d}, \mathrm{J}=3.6 \mathrm{~Hz})$ and the protons at C-6 in a allylic bond as one-proton double doublet at $\delta 4.75$ (brd, J $=10.2 \mathrm{~Hz}$ ) and $\delta 4.86$ (brdd, J=6.6, $10.8 \mathrm{~Hz}$ ) together with two methyl groups at $\delta 1.43$ and 1.71 (Kraut et al., 1994). (-)-ent-Costunolide (1) from $H$. paucistipula has known the major sesquiterpene lactone which had $1 \mathrm{H}$ and ${ }^{13} \mathrm{C}-\mathrm{NMR}$ data matching those reported for (+)-costunolide (3) (EI-Feraly et al., 1979; Kim et al., 1996). However, the optical rotation $\left([\alpha]_{D}-127^{\circ}\right)$ was opposite to the literature values for $3\left(+117^{0},+129^{0}\right)$ (Kim et al., 1996; Park et al., 1996). The minor sesquiterpene lactone was identified as (-)-ent-arbusculin B (4) since it showed the same ${ }^{1} \mathrm{H}$ and ${ }^{13} \mathrm{C}-\mathrm{NMR}$ data as those reported for $(+)-$ arbusculin B (5) (Greene et al., 1974; Kim et al., 1996), but had a negative optical rotation. We could only find two previous reports of the isolation of 4 , also known as (-)- $\gamma$-cyclocostunolide, from two Frullania species of liverwort methods (Asakawa et al., 1976; Asakawa et al., 1987). It is not surprising that germacranolide (1) and eudesmanolide, with the same rare $7 \alpha$ stereochemistry should co-occur, since eudesmanes are thought to be biosynthesised

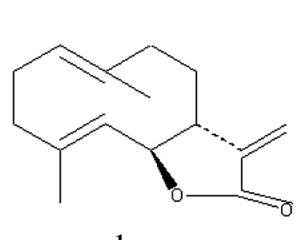

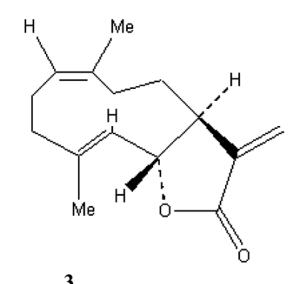

3

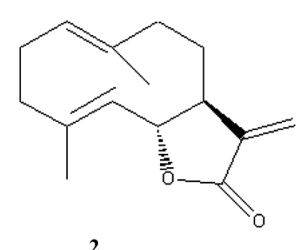

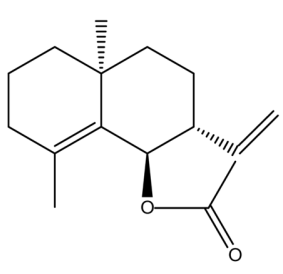

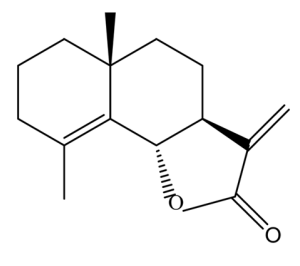

Fig. 1. The molecular structures of (-)-ent-costunolide (1), (+)-costunolide (2), 1(10)-cis-costunolide (3), (-)ent-arbusculin B (4) and (+)-arbusculin B (5). The sesquiterpene lactones (1, and 2$)$ have the same molecular formulas $\left(\mathrm{C}_{15} \mathrm{H}_{20} \mathrm{O}_{2}\right)$ and similar spectroscopic data which suggest similar structures. Differences however, exist in mp, optical rotation and NMR data. 1(10)-Cis-costunolide (3) has the different spectroscopic data and structure. However, Compound (3) has the same molecular formula. 


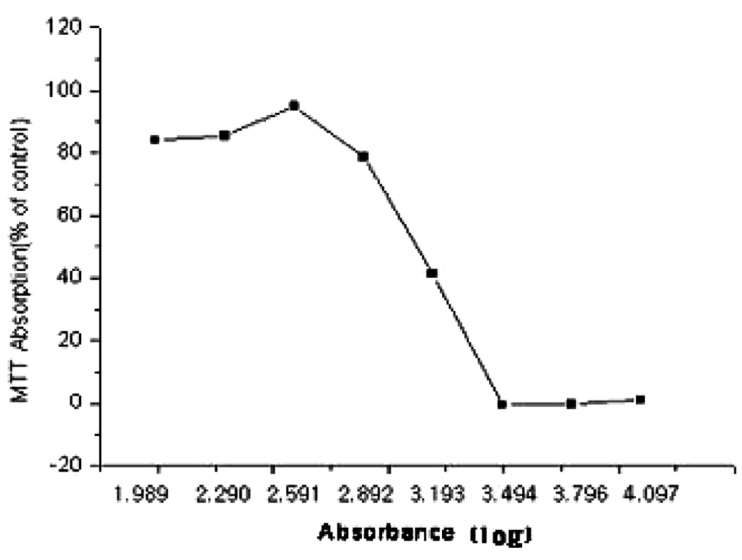

Fig. 2. In vitro cytotoxic effect of (-)-ent-costunolide (1) from $H$. paucistipula by the MTT method. This compound (1) was serially diluted in RPMI-1640 with $10 \%$ FBS and mixed with equal volume of murine leukaemia cells ATCC CCL 46 P388D1 (7.5 $\mu \mathrm{g} /$ disk). The colometric method was performed as described in materials and methods. Data are mean values of results obtained from three sets of experiments. In conclusion, (-)-ent-costunolide (1) has isolated from the whole plant of $H$. paucistipula, and we determined its structure by spectroscopic analysis. This sesquiterpene lactone (1) inhibited the growth of the dermatophytic fungus Trichophyton mentagrophytes ATCC 28185, (4 $\mathrm{mm}$ inhibition zone at $15 \mu \mathrm{g} /$ disc), cytotoxic activity to murine leukaemia cell lines ATCC CCL 46 P 388D1 $\left(\mathrm{IC}_{50} 687 \mathrm{ng} / \mathrm{Ml}\right.$, at $0.075 \mu \mathrm{g} /$ disk), BSC monkey kidney cell lines (100\% of well at $15 \mu \mathrm{g} /$ disk) and antiviral activity to Herpes simplex virus $(0.25 \mathrm{mg} / \mathrm{ml}, 100 \%$ of well at $7.5 \mu \mathrm{g} /$ disk) and Polio virus $(0.125 \mathrm{mg} / \mathrm{ml}$, $100 \%$ of well at $3.75 \mu \mathrm{g} /$ disk).

via germacrane intermediates (Fig. 1) (Cane et al., 1999).

\section{ACKNOWLEDGEMENTS}

We thank Dr. N. B. Perry at the Plant Extracts Research Unit, New Zealand Institute for Crop \& Food Research Ltd, Department of Chemistry, University of Otago in New Zealand. This work was supported by Wonkwang University in 2009.

\section{REFERENCES}

Asakawa Y. (1995) In progress in the Chemistry of Organic Natural Products, Vol. 65, p.1-185, Herz W,
Kirby GW, Moore RE, Steglich W, Tamm C, Eds.; Springer Vienma.

Asakawa Y, Matsuda R, Cheminat A. (1987) Bibenzyl derivatives form Frullaniaspecies. Phytochem. 26, 11171122.

Asakawa Y, Muller JC, Ourisson G, Foussereau J, Ducombs G. (1976) New sesquiterpene lactones of Frullania (Hepaticae). Isolation, structures, allergenic properties. Bull. Soc. Chim. Fr. (Chim. Mol.) 1465-1466.

Appendino G, Taglialatela-Scafati O, Romano A, Pollastro F, Avonto C, Rubiolo P (2009): Genepolide, a sesquiterpene gamma-lactone with a novel carbon skeleton from mountain wormwood (Artemisia umbelliformis) (perpendicular) J. Nat. Prod. In press.

BaekSH, Perry NB, Lorimer SD (2003): (-)-ent-Costunolide from the liverwort Hepatostolonophora paucistipula, J. Chem. Res. 14-15.

Baek SH, Perry NB, Weavers RT, Tangney RS. (1998) Geranyl phenyl ethers from the New Zealand liverwort Trichocolea hatcheri. J. Nat. Prod. 61, 126-129.

Baek SH, Lim JA, Kwag JS, Lee HO, Chun HJ, Lee JH, Perry NB. (2003) Screening for biological activity of crude extract and fractions from Brachyglottis monroi. Kor. J. Orien. Physiol. Pathol. 17, 826-828.

Baek SH, Shin JH, Chung WY, Han DS. (2000) Antitumor evaluation of cannabidiol and its derivatives by colorimetric methods. J. Toxicol. Pub. Health 16, 101107.

Beekman, A.C., Woerdenbag, H.J., Van Uden, W., Pras, N., Konings, A.W.T., Wiksöm, K.V., Schmidt, T.J., 1997. Structure-cytotoxicity relationships of some hele anolide -type sesquiterpene lactones. J. Nat. Prod. 60, 252-257.

Cane DE. (1999) In Isoprenoids incluing carotenoids and steroids, p. 155-200, Cane, DE, ed., Elsevier; Amsterdam.

Chen WM, Ralf M, Helmuth Z, Gerhard R. (1998) A non-oxidized melamolide and other germacranolides from Aristolochia yunnanensis. Phytochem. 28, 32333234.

EI-Feraly FS, Chan YM, Capiton GA, Doskotch RW, Fairchild EH. (1979) Isolation and characterization of peroxycostunolide (verlotorin) and peroxyparthenolide from Magnolia grandiflora. Carbon-13 nuclear magnetic resonance spectroscopy of costunolide and related compounds. J. Org. Chem. 44, 3952-3955. Greene AE, Muller JC, Ourisson G. (1974) Conversions 
of alpha-methyl to alpha-methylene-gamma-lactones. Synthesis of two allergenic sesquiterpene lactones. (-)-frullanolide and (+)-arbusculine B. J. Org. Chem. 39, 186-191.

Kim MJ, Oh HJ, Baek SH.(2005) Isolation and biological activity of sesquiterpene lactone. Kor. J. Orien. Physiol. Pathol. 19, 1375-1378.

Kraut L, Mues R, Sim-Sim M. (1994) Sesquiterpene lactones and 3-benzylphthalides from Frullania muscicola. Phytochem. 37, 1337-1346.

Kim YC, Bolzani VDS, Baj N, Gunatilaka AAL, Kingston DGI. (1996) A DNA-damaging sesquiterpene and other constituents from Frullania nisquallensis. Planta Med. 62, 61-63.

Kim MJ, Baek SH (2006) Antifungal activity of (-)-entcostunolide on the dermatophytic fungus Trichophyton mentagrophytes, Kor. J. Orien. Physiol. Pathol. 20, 467470.

Kim MJ, Lee JS, Baek SH (2009) In vitro cytotoxic activity of (-)-ent-costunolide. Orien. Pharm. Exp. Med. 9, 97-99, 2009.

Kupchan SM, Eakin MA, Thomas AM. (1971) Tumor inhibitors. 69. Structure-cytotoxicity relations among the sesquiterpene lactones. J. Med. Chem. 14, 11471152.

Lee, K.H., Hall, I.H., Mar, E.C., Starnes, C.O., ElGebaly, S.A., Waddell, T.G., Hadg aft, R.I., Ruffner, C.G., Weidner, I., 1997. Sesquiterpene antitumor agents: inhibitors of cellular metabolism. Science (Wash. DC) 196, 533-535.

Lyss, G., Knorre, A., Schmidt, T.J., Pahl, H.L., Merfort, I., 1998. The anti-inflammatory sesquiterpene lactone helenalin inhibits the transcription factor NF-nB by directly targeting p65. J. Biol. Chem. 273, 33508-33516.

Park HJ, Jung WT, Basnet P, Kadota S, Namba T. (1996) Syringin 4-O- $\beta$-glucoside,a new phenylpropanoid glycoside, and costunolide, a nitrite oxide synthase inhibitor, from the stem bark of Magnolia sieboldii. J. Nat. Prod. 59, 1128-1130.

Shin JH, Oh HJ, Park NK, Kim YH, Jeong JH, Lee JH, Baek SH. (2001): Isolation of cytotoxic component from Trichocolea hatcheri. Orient. Pharm. Exp. Med. 1, 49-56.

Stocking EM, Williams RM (2003): Chemistry and biology of biosynthetic Diels-Alder reactions, Angew. Chem., Int. Ed. 42, 3078-3155.

Schmidt, T.J., 1997. Rates and stereochemistry in the reaction of helenalin and related helenanolides with sulfhydryl containing biomolecules. Bioorg. Med. Chem. 5, 645-653.

Zhang S, Won YK, Ong CN, Shen HM (2005): Anticancer potential of sesquiterpene lactones: bioactivity and molecular mechanisms. Curr. Med. Chem. Anticancer Agents. 5, 239-249. 